\title{
Distribution of polychlorinated biphenyl residues in several tissues of fish from the North End Lake, Port Elizabeth, South Africa
}

\author{
E Kampire ${ }^{1 *}$, G Rubidge' and JB Adams ${ }^{2}$ \\ 'Nelson Mandela Metropolitan University, Department of Chemistry; P.O. Box 77000 Port Elizabeth, 6031, South Africa \\ ${ }^{2}$ Nelson Mandela Metropolitan University, Department of Botany, P.O. Box 77000 Port Elizabeth, 6031, South Africa
}

\begin{abstract}
The concentrations and distribution of 6 PCB indicator congeners (IUPAC nos. 28, 52, 101, 138, 153, and 180) were measured in 236 organ samples of fish (Cyprinus carpio and Oreochromis mossambicus) from the North End Lake in Port Elizabeth, South Africa. Polychlorinated biphenyls (PCBs) were extracted from the fish muscles, gills, gonads and livers using USEPA method 8082, followed by a clean-up using concentrated sulphuric acid and florisil column chromatography. Analysis was achieved by gas chromatography-mass spectrometry (GC/MS) using the internal standard method. The concentrations of total PCBs in the liver, gonads, gills and muscle were $95.69,57.49,44.63,34.14 \mathrm{ng} \cdot \mathrm{g}^{-1}$ lipid weight (lw) in C. carpio and 119.73 , $59.21,49.78,34.63 \mathrm{ng} \cdot \mathrm{g}^{-1}(\mathrm{lw})$ in $O$. mossambicus, respectively. These values were relatively low compared to those reported in the literature. PCB levels were predictably highest in the lipid-rich livers. Individual congeners were not distributed homogeneously within the investigated organs. PCBs 153 and 138 were present at higher concentrations than other PCB congeners for both species. PCB contaminants in fish act as indicators of pollution in aquatic ecosystems and are a potential threat to human health when consumed.
\end{abstract}

Keywords: PCBs, tissues, fish, GC/MS, biomagnification, North End Lake

\section{INTRODUCTION}

Polychlorinated biphenyls (PCBs) are synthetic chemicals made up of 209 isomers classified as persistent organic pollutants (POPs). They are bioaccumulative substances, causing serious damage to the environment, and have been identified worldwide (Ahmed, 2003; Hu et al., 2010; Cimenci et al., 2013; Gdaniec-Pietryka et al., 2013).

PCBs were introduced into the environment primarily as a result of anthropogenic activities (Iwata et al., 1993). Due to their resistance to electrical, thermal, and chemical processes, PCBs have been used in a wide variety of applications since their commercial production in 1929 (Anyasi and Atagana, 2011).

Exposure to PCBs has been reported to cause adverse effects, including reproductive, immunological and neurological problems, while long-time exposure to some congeners affects liver functioning and may lead to developmental effects resulting in cancer (ATSDR, 2000). One of the main sources of these compounds to humans is dietary fish, which accumulate pollutants by direct absorption through the gills, exposure to contaminated sediments, and consumption of insects and smaller fish (Bush and Kadlec, 1995). In consequence, fish can accumulate hydrophobic compounds (e.g. PCBs) to concentrations considerably higher than those of the surrounding environment (OSPAR, 2004). The highest PCB concentrations are detected in lipid-rich tissues such as the liver and the muscle of fatty fish. Because of the persistence of these contaminants and the resulting harmful effects to organisms and human health, it is necessary to continue to monitor their distribution in the environment (Toaspern, 2003).

\footnotetext{
* To whom all correspondence should be addressed. - +27 78606 0267; e-mail: edkampire@gmail.com Received 9 November 2014; accepted in revised form 17 June 2015
}

Fish consumption is an important constituent of human diets in that it increases the intake of omega-3 fatty acids which in turn lowers cholesterol, cancer risks, and blood pressure levels. However, despite the beneficial aspects of consumption, fish may also contain contaminants such as trace elements, PCBs or other pollutants.

Currently, very high resolution capillary columns are able to separate the 209 PCB congeners. However, the analysis of extracts of a biological matrix is still difficult because of co-elution. The six non-dioxin-like (NDL) PCBs (PCB nos. $28,52,101,138,153,180)$ used as indicators are representative of the congeners used in the PCB mixtures in the past and of the PCBs found in the environment at the present time (Aune et al., 1999). The sum of these congeners represents about $50 \%$ of the total non-dioxin-like PCBs in food (EFSA, 2005), and is recommended for regular monitoring (UNEP, 2003).

In aquatic organisms, most studies have reported on PCBs in the muscles of fish (Baeyens et al., 2007, Kočan et al., 2001). While industries are a key component of the country's economy, little research has been conducted on PCB contamination and no literature is available for PCB analysis in different organs of fish from the North End Lake. The purpose of the study was: to evaluate the levels of 6 indicator congeners of PCBs in organs of 2 fish species collected from the North End Lake, provide background information on the status of PCB contamination in the studied area, and evaluate the human health risks from consumption of fish muscle. There is increased environmental concern due to South Africa's growing chemical industry that has in turn led to increased industrial waste. The North End Lake is targeted for future recreational use; however, no literature is available regarding the current water quality status, particularly concerning persistent organic pollutants. In addition, the system is popular amongst local fishermen that catch, sell and consume the fish, even though it is potentially contaminated lake. 


\section{MATERIALS AND METHODS}

\section{Study area}

The North End Lake (Fig. 1) is an urban water body $\left(33^{\circ} 56^{\prime} \mathrm{S}\right.$, $25^{\circ} 36^{\prime} \mathrm{E}$ ) in the middle of a residential and industrial suburb, that of North End, Port Elizabeth, South Africa. The lake is situated adjacent to the new soccer stadium, which was built for the 2010 FIFA World Cup. The stadium was specially designed to have views of the lake on one side and the ocean on the other side. Water from the North End Lake is treated and utilized for irrigating green areas in the stadium. Repeated watering of the grass with PCB-contaminated water could result in PCB accumulation on the sports field inside the enclosed stadium. The maximum depth of the lake is about $4 \mathrm{~m}$ (on average $3 \mathrm{~m}$ ). The water level of the lake is controlled at a maximum height of $16.3 \mathrm{~m}$ amsl by means of an overflow leading to an underground concrete culvert, which flows into the sea. For several decades the lake was one of the main recreational areas of the city. As the city expanded, the lake was increasingly subjected to human impacts (Weichers et al., 1996), with an increased inflow from residential and industrial stormwater runoff drains (Fig. 1).

\section{Fish collection}

During February, August and November of 2013, 60 fish from 2 species (C. carpio and O. mossambicus) were bought from the same fisherman at the lake. C. carpio was found to be the most abundant species caught in the lake $(n=51)$, while O. mossambicus $(n=9)$ originated from a single catch (23 February 2013). These two species may accumulate high levels of contaminants as they are omnivorous (O. mossambicus) and bottom-feeders (C. carpio). After sampling, fish were transported to the laboratory on ice, weighed, measured and wrapped in aluminium foil. All fish were assigned an identification number and letter code. Fish were stored in a deep freezer at $-20^{\circ} \mathrm{C}$ until further analysis. After dissection, samples of different organs (liver, gills, muscle and gonads) were taken from each fish and analysed individually. In total, 236 samples from fish organs were processed and analysed. The length $(\mathrm{cm})$, weight $(\mathrm{g})$ and the condition factor of the two fish species investigated are shown in Table 1.

\section{Chemicals and reagents}

All the chemicals used were of analytical grade. Standards of individual PCB congeners, together with the mixture of the six indicator PCBs in isooctane (10 ng. $\mu \ell^{-1}$ of each congener), PCB 209 and a solution of 2,4,5,6-tetrachloro- $m$-xylene used as internal/surrogate standard were obtained from Sigma Aldrich (South Africa).

The analysis and quantification method was performed using congener-specific methods (SW-846 Method 8082). Therefore, decachlorobiphenyl (PCB 209) is recommended for use as an internal standard with tetrachloro- $m$-xylene used as a

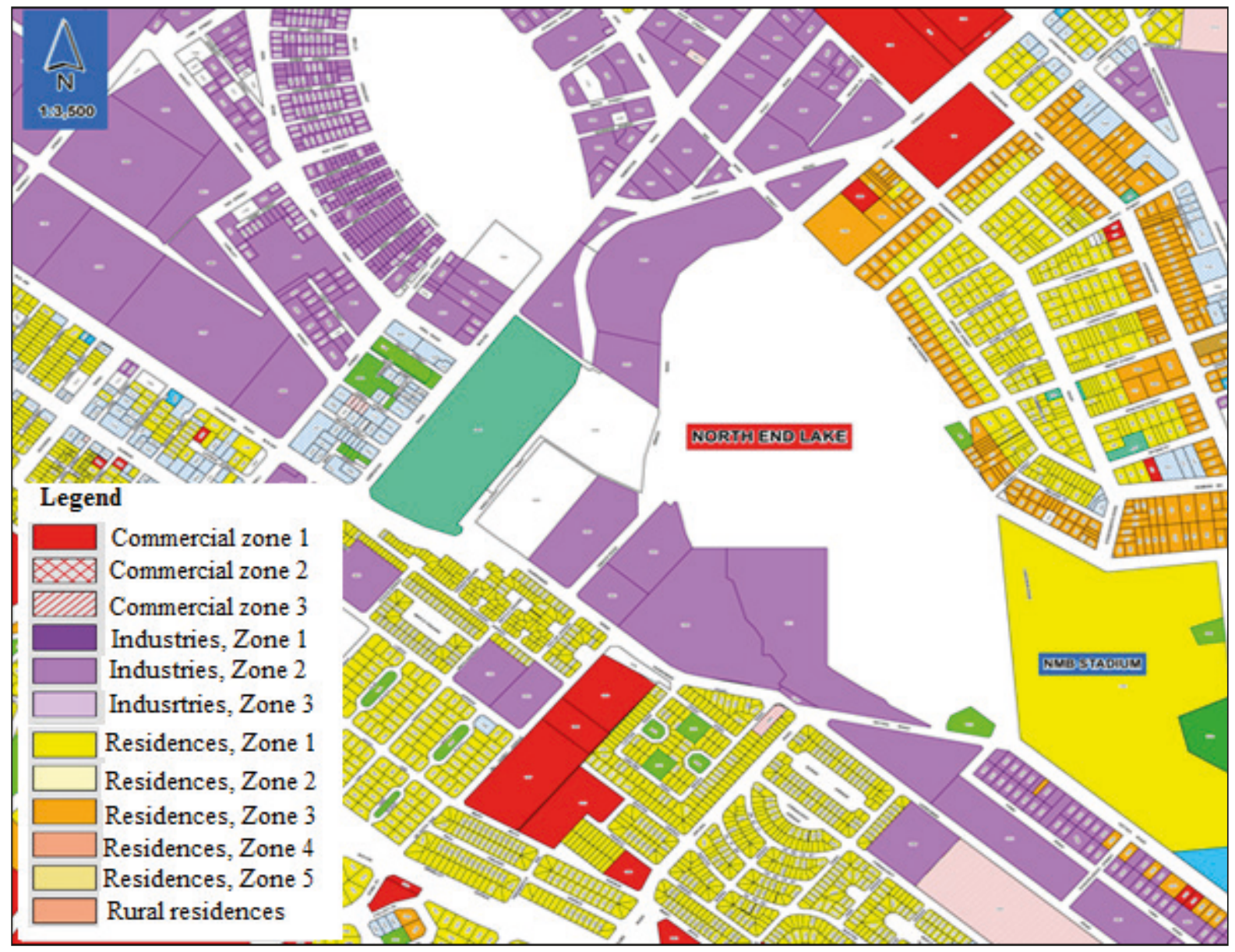

Figure 1

Study area: The North End Lake and land use of surrounded area 
TABLE 1

Biometric data of the two fish species analysed

\begin{tabular}{|c|c|c|c|c|c|c|c|}
\hline \multirow[t]{2}{*}{ Fish species } & \multicolumn{3}{|c|}{ Body length $(\mathrm{cm})$} & \multicolumn{3}{|c|}{ Body weight (g) } & \multirow{2}{*}{$\begin{array}{c}\text { Condition factor (CF) } \\
\qquad\left(\mathbf{g} \cdot \mathrm{cm}^{-3}\right)\end{array}$} \\
\hline & Min & Max & Mean \pm SD & Min & Max & Mean \pm SD & \\
\hline $\begin{array}{l}\text { Oreochromis } \\
\text { mossambicus }(n=9)\end{array}$ & 29 & 35 & $32 \pm 2$ & 550 & 1056 & $800 \pm 156$ & $2.3(1.83-2.54)$ \\
\hline Cyprinus carpio $(n=51)$ & 15 & 48 & $32 \pm 7$ & 211 & 1521 & $841 \pm 332$ & $1.53(0.92-2.5)$ \\
\hline
\end{tabular}

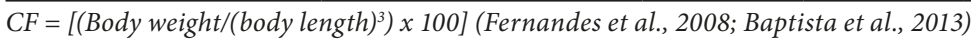

surrogate. PCB-209 is rarely present or undetectable in commercial mixtures and is a by-product in very few manufacturing processes.

The purity of the standards was greater than $99 \%$. A stock standard solution containing all six PCB congeners was prepared at a concentration of $1 \mathrm{ng} \cdot \mu \mathrm{\ell}^{-1}$. Suitable working PCB solutions were prepared daily by dilution in isooctane. All stock solutions were stored between 2 and $6^{\circ} \mathrm{C}$, protected from light. The solvents and reagents used (n-hexane, acetone, isooctane, anhydrous sodium sulphate, sulphuric acid (98\%) and silanetreated glass wool) were all supplied by Merck (South Africa). Florisil (60-100 mesh) was obtained from Sigma Aldrich.

\section{Analytical procedures}

Determination of PCBs in environmental samples consisted of 3 main steps: (i) extraction, (ii) purification/fractionation of the extract and (iii) chromatographic separation, identification/ quantification.

\section{Sample preparation}

The preparation of fish samples followed USEPA (2000a) guidance. Before dissection, fish were thawed to remove the aluminium foil, and then rinsed with tap water followed by deionized water. The fillet was taken from the left side of the fish above the lateral line and below the dorsal area. Other organs to be analysed were removed and kept separately. Gonad, liver and gill samples were ground in a mortar with 4 times more anhydrous sodium sulphate than the sample mass until homogenous form appeared. Muscle samples were blended and the result was mixed with anhydrous sodium sulphate in a mortar for dehydration and homogenization of the samples. Briefly, muscle (10 $\mathrm{g})$, gonad/liver ( $1 \mathrm{~g})$, and gill ( $\mathrm{g}$ ) were dried before the extraction with sodium sulphate; (1:3 muscle tissue: sodium sulphate; 1:4 gonad, liver or gill organ: sodium sulphate).

\section{Extraction of fish samples}

The extraction of the PCB in fish tissues was performed according to standard procedures (USEPA, 1996) with slight modifications (extracts were concentrated to $2 \mathrm{~m} \ell$ rather than $10 \mathrm{~m} \ell$ ). Surrogate standard (tetrachloro- $m$-xylene) was added to each sample prior to the extraction. The sample was then extracted using a mixture of hexane and acetone (1:1) for 20-22 $\mathrm{h}$ in a Soxhlet apparatus cycling 5-6 times $\cdot \mathrm{h}^{-1}$. The extract was concentrated to $2 \mathrm{m \ell}$ with a rotary evaporator at $40^{\circ} \mathrm{C}$. The concentrated extract was divided into 2 subsamples $(1 \mathrm{ml}$ was used for clean-up and the remaining extract was used for gravimetric lipid determination). However, not all the lipids are extracted by this procedure, only the lipids extracted by the solvent mixture.

\section{Clean-up of the extracts}

The clean-up procedure was accomplished by strong acid treatment followed by partitioning with florisil. Briefly, concentrated sulphuric acid $(2 \mathrm{~m} \ell)$ was added to the extract $(1 \mathrm{~m} \ell)$ and shaken vigorously to eliminate interfering co-extracts. The procedure was repeated several times until the acid phase remained colourless. The extract was dried with anhydrous sodium sulphate and subjected to fractionation using florisil. A glass column was packed with $10 \mathrm{~g}$ of florisil (60-100 mesh) and $2 \mathrm{~g}$ of $\mathrm{Na}_{2} \mathrm{SO}_{4}$ anhydrous was added on the top for removal of any trace of water. The extract $(1 \mathrm{ml})$ was loaded onto the column and PCBs were eluted with $80 \mathrm{~m} \ell$ of hexane. The eluates were concentrated by rotary evaporator and a gentle nitrogen stream. PCB fraction was dissolved in $1 \mathrm{~m} \ell$ of hexane and transferred in gas chromatograph vials prior to the gas chromatography analysis. A known quantity of internal standard (IUPAC no. 209) was added to the cleaned extract and was analysed by GC-MS in single ion monitoring (SIM) mode for the determination and quantification of PCB congeners.

\section{Determination of PCB congeners}

The determination of PCBs in fish samples was carried out using a Hewlett-Packard 7890 gas chromatograph coupled with a Hewlett Packard Model 5975 mass selective detector (mass analyzer: quadrupole) and an automatic sampler. The fused silica capillary column was a $30 \mathrm{~m} \mathrm{DB}-1 \mathrm{~ms}$ (100\% dimethylsiloxane) (CJ \&W Scientific, CA, USA) $(0.25 \mathrm{~mm}$ i.d. x $0.25 \mu \mathrm{m}$ film thickness). The oven temperature was programmed from an initial temperature of $100^{\circ} \mathrm{C}$ (holding for $1 \mathrm{~min}$ ) to $325^{\circ} \mathrm{C}$ at a rate of $15^{\circ} \mathrm{C} / \mathrm{min}$ and held for $5 \mathrm{~min}$. The injector and transfer line temperatures were 250 and $280^{\circ} \mathrm{C}$, respectively. The carrier gas was helium at a constant flow rate of $1.2 \mathrm{~m} \ell \cdot \mathrm{min}^{-1}$. Injection volume was $1 \mu \ell$ in splitless mode. Data were acquired in the electron impact (EI) mode $(70 \mathrm{eV})$ and the MS was operated in the selected ion monitoring (SIM) mode. The following quantifying and qualifying ions were monitored: $\mathrm{m} / \mathrm{z}$ values are 258 , 256 and 186 for PCB 28; 292, 290 and 220 for PCB 52; 326, 324 and 256 for PCB 101; 362, 360 and 290 for PCBs 153 and 138; 396, 394 and 324 for PCB 180, 498, 500 and 428 for PCB 209.

\section{PCB identification and quantification}

The identification of target compounds was based on the retention times and spectra, as well as the ion ratio. PCBs were quantified by internal standard method using peak areas. SIM mode was used in MS analysis and 2 masses were monitored for each analyte ( 2 most intense peaks within the mass spectrum). Retention time shifts in the chromatogram were corrected using the internal standard retention time and positive confirmation of the analyte was based on an agreement within $\pm 0.1 \mathrm{~min}$ of 
the expected retention time. To determine the linear range of the detector, several standard solutions were prepared and injected at different concentration levels. Calibration curves covered a range of 10-200 ng.m $\ell^{-1}$. For all compounds, the linear regression was accepted if the correlation coefficient $\left(r^{2}\right)$ was greater than 0.99 . The precision was determined by calculating the relative standard deviation (RSD) of the replicate samples which was $\leq 20 \%$.

\section{Quality assurance and data analysis}

All of the procedures were controlled strictly by the analysis of procedural blank samples as well as the recoveries of surrogate standard in each sample. Procedural blanks were run with each batch of samples (8 samples per batch) and were taken through all the phases of the analytical procedure. To determine the extent of recovery, muscles of C. carpio with an initial PCB content below the detection limit were spiked with PCB standards at 3 levels $(5,10$ and $20 \mathrm{ppb})$. The mean recovery of PCBs from 6 replicate samples were $91.4 \pm 3.84 ; 97.6 \pm 2.08 ; 107 \pm 4.83 ; 92.15$ $\pm 5.65 ; 95.48 \pm 2.65$ and $98.25 \pm 3.25$ for PCBs $28,52,101,138$, 153 and 180, respectively. C. carpio was chosen because it was the most abundant species in the study area and was expected to be the most frequently analysed fish in the future. The detection limit (LOD) and limit of quantification (LOQ) were defined, respectively, as 3 and 10 times the standard deviation of all analysed blanks. The LOD varied with analytes: $0.48,0.16$, $0.02,0.09,0.07$ and $0.12 \mathrm{ng} \cdot \mathrm{g}^{-1}$, respectively, for PCB 28, 52, 101, 138,153 and 180. The values of LOQ were 1.59, 0.54, 0.05, 0.31, 0.24 and $0.39 \mathrm{ng}^{-1} \mathrm{~g}^{-1}$, respectively, for PCBs $28,52,101,138,153$ and 180. For the extraction purpose, $10 \mathrm{~g}$ of muscle tissue, $1 \mathrm{~g}$ of liver/gonad and $3 \mathrm{~g}$ of gills were used to extract PCBs.

The data were analysed with Statistica 11.0 software.
Statistical significant differences were determined using oneway analysis of variance (ANOVA) and Pearson test was used to assess correlations between contaminant concentrations and lipid content/size of fish. During statistical analysis, nondetectable (nd) data were assigned a half-value of the limit of quantification. All tests were considered statistically significant when the $p$-value $<0.05$.

\section{RESULTS}

\section{Levels and distribution of PCBs in fish tissues}

The mean concentrations of individual congeners and total PCBs for both species are summarized in Tables 2 and 3 . Total PCBs in C. carpio and O. mossambicus ranged from $34.14 \pm$ 14.88 to $95.69 \pm 24.56$ and from $34.63 \pm 18.44$ to $119.73 \pm 1$ $6.06 \mathrm{ng} \cdot \mathrm{g}^{-1}$ lipid weight (lw) with an average of $57.99 \pm 26.89$ and $65.84 \pm 37.71 \mathrm{ng} \cdot \mathrm{g}^{-1} \mathrm{lw}$, respectively. Potential target organs for the accumulation of PCB congeners were identified. The liver represented the major target organ for PCBs, receiving the largest part (41\% and $45 \%$ ) of overall contaminant for C. carpio and O. mossambicus, respectively. Total PCBs in gills of both species

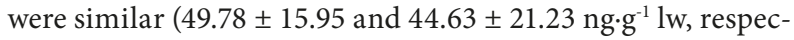
tively, in O. mossambicus and C. carpio). Significant differences were observed between PCB levels of liver and other organs in each species (ANOVA $p<0.05$ ). However, no significant differences were observed between the mean PCB concentrations in gills, muscles, livers and gonads of both fish species $(p>0.05)$.

\section{PCB congener's profiles}

The percentage contributions of the six indicators to the total PCBs in organs of both species are shown in Figs 2a and b. In

\begin{tabular}{|l|c|c|c|c|}
\hline \multicolumn{5}{|c|}{ TABLE $\mathbf{2}$} \\
\hline Analytes & Muscle $(\boldsymbol{n}=\mathbf{5 1})$ & Gills $(\boldsymbol{n}=\mathbf{5 1})$ & Gonads $(\boldsymbol{n}=\mathbf{4 8})$ & Liver $(\boldsymbol{n}=\mathbf{5 0})$ \\
\hline PCB 28 & $3.66 \pm 4.64$ & $7.01 \pm 7.66$ & $7.31 \pm 8.35$ & $12.78 \pm 8.47$ \\
\hline PCB 52 & $3.44 \pm 3.81$ & $6.69 \pm 7.11$ & $7.00 \pm 7.09$ & $12.77 \pm 7.67$ \\
\hline PCB 101 & $5.44 \pm 5.96$ & $6.86 \pm 6.43$ & $9.14 \pm 10.56$ & $14.88 \pm 7.70$ \\
\hline PCB 138 & $7.45 \pm 5.81$ & $7.80 \pm 5.80$ & $12.24 \pm 7.05$ & $20.90 \pm 10.12$ \\
\hline PCB 153 & $8.57 \pm 6.49$ & $8.30 \pm 7.22$ & $12.79 \pm 9.72$ & $19.27 \pm 8.34$ \\
\hline PCB 180 & $5.59 \pm 4.84$ & $7.95 \pm 5.27$ & $9.01 \pm 6.97$ & $15.09 \pm 9.58$ \\
\hline$\square_{6}$ PCBs & $34.14 \pm 14.88$ & $44.63 \pm 21.23$ & $57.49 \pm 23.12$ & $95.69 \pm 24.56$ \\
\hline$\%$ lipid content & $2.26 \pm 1.15$ & $2.53 \pm 1.48$ & $2.77 \pm 1.45$ & $3.03 \pm 1.73$ \\
\hline
\end{tabular}

\begin{tabular}{|l|c|c|c|c|}
\hline \multicolumn{5}{|c|}{ TABLE 3 } \\
PCB levels in O. mossambicus tissues $\left(\boldsymbol{n}=\mathbf{9}, \mathbf{n g} \cdot \mathbf{g}^{-1}\right.$ Iw basis, mean \pm standard deviation) \\
\hline Analytes & Muscle $(\boldsymbol{n}=\mathbf{9})$ & Gills $(\boldsymbol{n}=\mathbf{9})$ & Gonads $(\boldsymbol{n}=\mathbf{9})$ & Liver $(\boldsymbol{n}=\mathbf{9})$ \\
\hline PCB 28 & $6.47 \pm 6.94$ & $7.89 \pm 5.48$ & $9.45 \pm 10.60$ & $15.26 \pm \mathbf{6 . 5 7}$ \\
\hline PCB 52 & $3.42 \pm 2.33$ & $7.97 \pm 4.93$ & $7.97 \pm 4.66$ & $17.73 \pm \mathbf{6 . 3 4}$ \\
\hline PCB 101 & $6.38 \pm 4.54$ & $8.34 \pm 6.77$ & $8.50 \pm 5.49$ & $16.90 \pm \mathbf{3 . 1 3}$ \\
\hline PCB 138 & $5.54 \pm 5.15$ & $7.04 \pm 4.14$ & $9.67 \pm 4.52$ & $28.24 \pm \mathbf{5 . 9 8}$ \\
\hline PCB 153 & $6.50 \pm 5.79$ & $11.08 \pm 3.90$ & $12.87 \pm 4.91$ & $23.21 \pm \mathbf{6 . 0 4}$ \\
\hline PCB 180 & $6.32 \pm 4.86$ & $7.45 \pm 4.29$ & $10.75 \pm 4.02$ & $18.40 \pm 7.05$ \\
\hline$\triangle_{6}$ PCBs & $34.63 \pm 18.44$ & $49.78 \pm 15.95$ & $59.21 \pm 25.82$ & $119.73 \pm \mathbf{1 6 . 0 6}$ \\
\hline \% Lipid content & $2.63 \pm 0.91$ & $2.83 \pm 1.25$ & $3.27 \pm 1.70$ & $3.44 \pm 1.44$ \\
\hline
\end{tabular}


general, congeners with 5, 6 and 7 chlorine atoms were quantitatively more important in all organs, with predominance of hexachlorobiphenyls (138 and 153), which contributed to 35\% and $45 \%$, on average, of the total PCBs in both species.

PCB 28 was dominant in muscle of $O$. mossambicus (mean of $6.47 \pm 6.94 \mathrm{ng} \cdot \mathrm{g}^{-1} \mathrm{lw}$ ) and contributed to the total PCBs equally as PCB 153 (19\%). Similarly, PCBs 101 and 180 contributed $18 \%$ each to the total PCBs in muscle. PCB 153 contributed to the total PCBs in gills and gonads with the same amount (22\%). With respect to bioamagnification, a higher occurrence of PCBs in O. mossambicus $(100 \%)$ relative to $C$. carpio is expected due to its diet including algae, plant matter, sediment organic particles, small insects, invertebrates and other fish which would already have biomagnified the PCBs.

In C. carpio, the lower congeners (PCBs 28 and 52) as well as PCBs 101 and 180 contributed, on average, $<20 \%$ each to the total PCBs. Both hexachlorobiphenyls (PCBs 138 and 153) contributed, on average, $>20 \%$ to the total PCBs in liver, muscle and gonads.

Statistically significant differences were observed between individual congeners in tissues $(p<0.05)$. PCB 153 was significantly higher than PCBs 28, 52, 101 and 180 (ANOVA $p<0.05$ ) in all the tissues. Similarly, PCB 138 was significantly higher than PCBs 28, 52, and 101 in liver. Furthermore, no significant difference was observed between congeners in gills and gonads (ANOVA $p>0.05$ ).

\section{Biological and biochemical parameters}

The size of an organism is dependent on the availability of food providing the energy needed for the organism to form body tissues and to tolerate adverse environmental conditions. The size of fish is used as an indicator of PCB contamination levels. The contaminant/length relationship occurs due to the older age of larger fish, which have a longer exposure period to contaminants. The mean size and weight for the 51 C. carpio analysed was $32 \pm$ $7 \mathrm{~cm}$ and $841 \pm 332 \mathrm{~g}$, respectively. For O. mossambicus, the mean size and weight of the 9 fish analysed was $32 \pm 2 \mathrm{~cm}$ and $800 \pm$ $147 \mathrm{~g}$, respectively. The condition factor (CF) was calculated from the weight of the fish in relation to its size [CF = (body weight/ $\left.(\text { size })^{3}\right) \mathrm{x}$ 100]. The condition factor serves as an indicator of growth, nutritional state and energy content of the fish. For both species, the CF showed good condition with means of $2.3 \pm 0.2$ $\mathrm{g} \cdot \mathrm{cm}^{-3}$ and $1.53 \pm 0.34 \mathrm{~g} \cdot \mathrm{cm}^{-3}$, respectively, in O. mossambicus and C. carpio. A significant positive relationship between body size $(\mathrm{cm})$ and concentrations of PCBs was observed in the tissues of both species $(p<0.05)$, except in liver and gonads of O. mossambicus ( $p>0.05$ ) (Figs 3a and 3b).
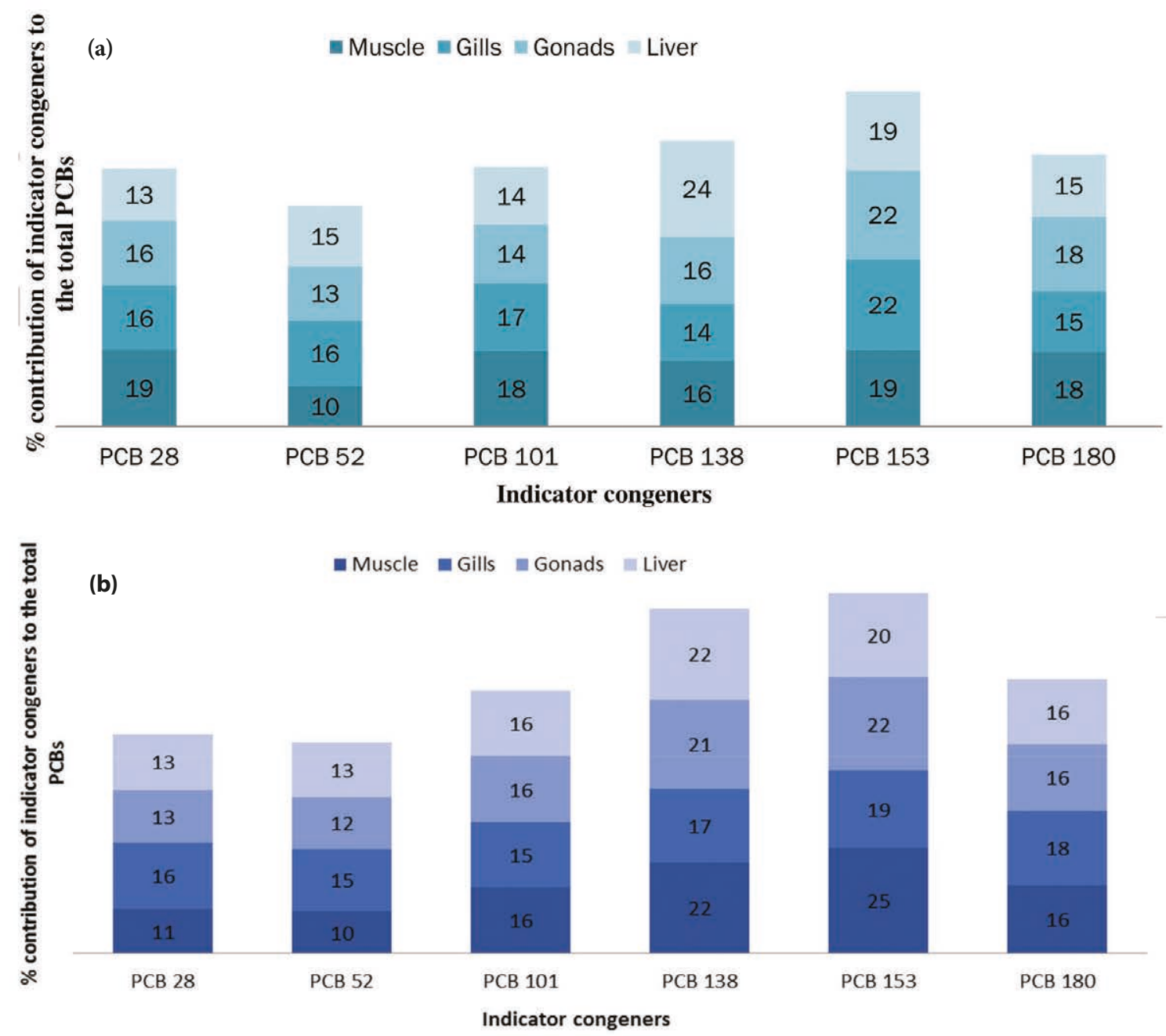

Figure 2

Contribution of indicator congeners to the total PCBs in (a) O. mossambicus and (b) C. carpio 

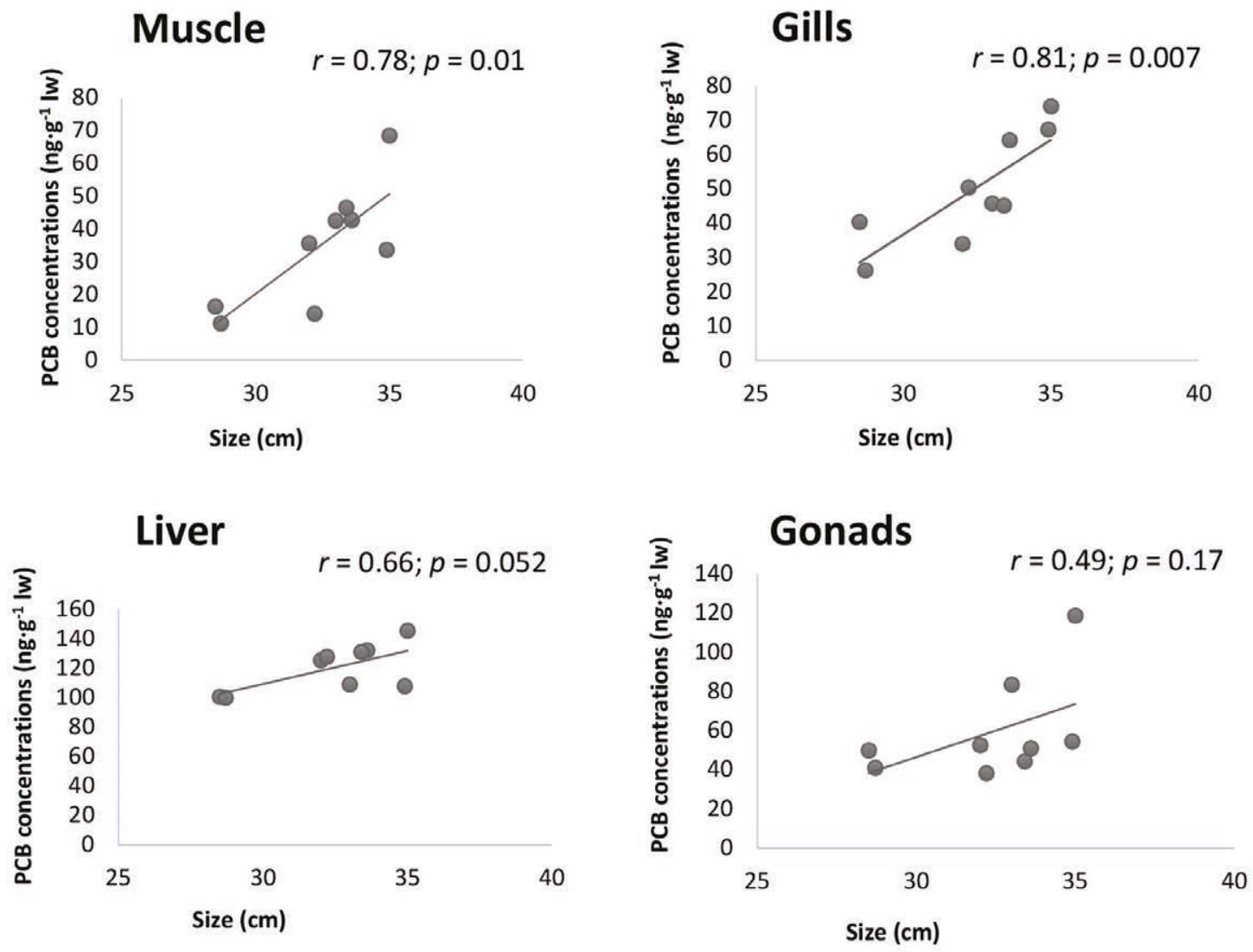

Figure $3 a$

$P C B$ concentrations in tissues of $\mathrm{O}$. mossambicus as function of size $(\mathrm{cm})$
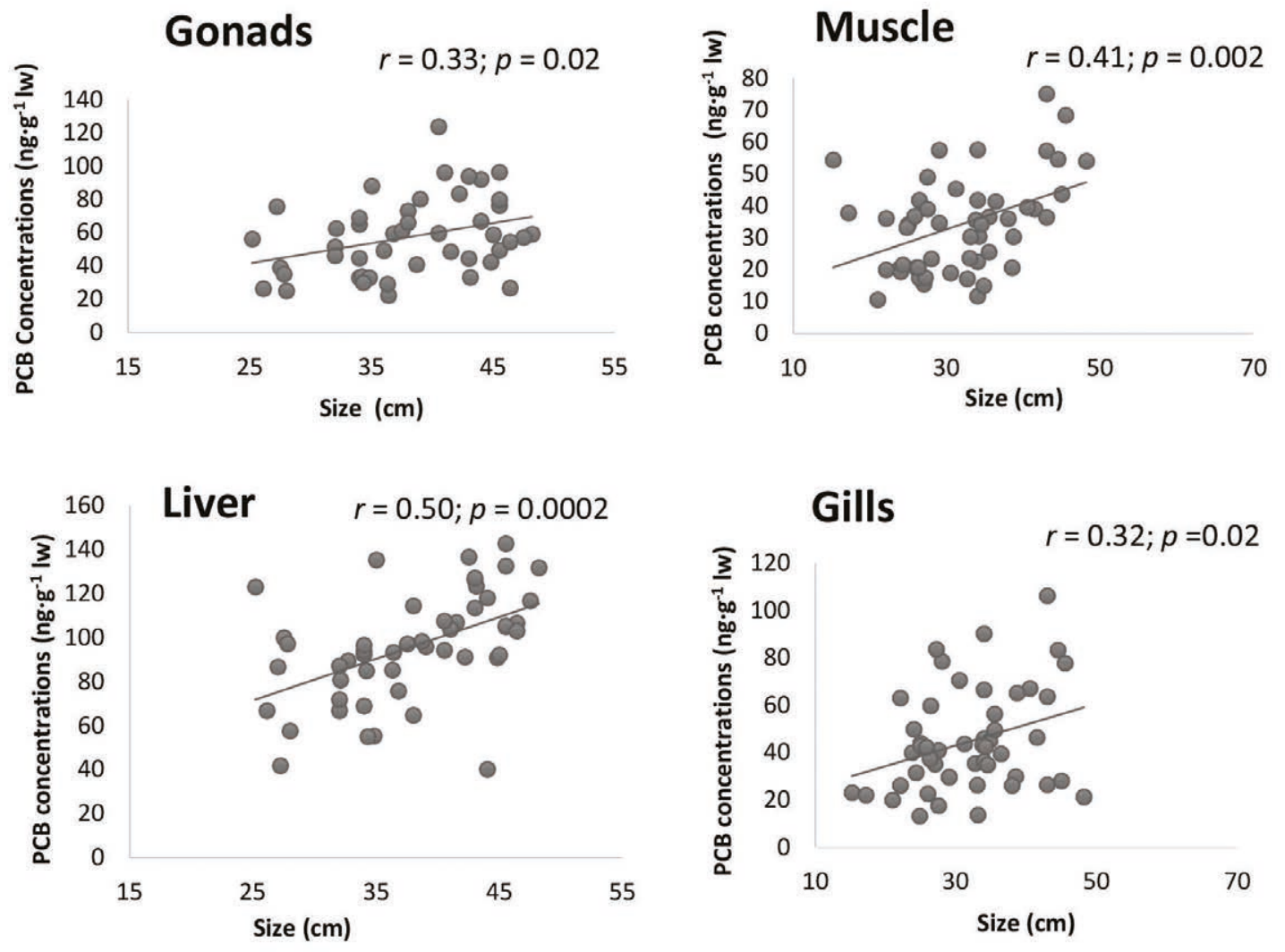

Figure 36

$P C B$ concentrations in tissues of $C$. carpio as function of size $(\mathrm{cm})$ 
Since PCB compounds are hydrophobic (high Kow), their concentrations based on amounts of lipids are considered to be an important variable in their distribution in fish. The liver had the highest levels of lipid content in both species in comparison to the other tissues, followed by gonads, gills and muscle. Figures $4 \mathrm{a}$ and $4 \mathrm{~b}$ showed the relationship between lipid content and PCB concentrations in O. mossambicus and C. carpio, respectively. A positive correlation between lipid content and contaminant levels was observed in tissues of both species, except in liver of $O$. mossambicus and in gills of $C$. carpio $(p>0.05)$. These results highlight the effect of size and lipid content on PCB levels and differences between organs.

\section{DISCUSSION}

Fish act as indicators of $\mathrm{PCB}$ pollution in the aquatic ecosystems where they store chemical substances either directly from the surrounding environment or from their diet (Lavandier et al., 2013). These contaminants in fish are a threat to predators and humans when consumed due to the fact that PCBs are soluble in the lipids fraction, especially the higher chlorobiphenyls, thereby increasing their bioaccumulation and biomagnification (Urbaniak, 2007; Beyer and Biziuk, 2009). Geyer et al. (1994) mentioned that fish lipid content varies according to species, age, sex, season and location. Mainly, PCBs enter into aquatic organisms via lipids of the ingested food (Hites et al., 2004), while their distribution in tissues is strongly influenced by their lipid content (Henshel and Sparks, 2006). The lipid plays a role in physiological processes of fish such as reproduction. The accumulation of organochlorine compounds shows that the reproductive cycle is associated with a large variation in lipid content (Antunes et al., 2007). Lipid content decreases during the spawning period by the elimination of lipid-bound hydrophobic compounds, such as POPs (Ondarza et al., 2014). Lipid content is among the most important factors that determine species body burden. A positive correlation was found between lipid content and PCB concentrations, which is in accordance with other studies. Previous investigations carried out on aquatic organisms showed that there is a correlation between the accumulation of PCB and the lipid content of tissues (Hebert and Keenleyside, 1995; Kočan et al., 2001).

These findings confirm that lipid content is one of the main factors involved in PCB accumulation in fish. However, a study by Nie et al. (2005) indicated that several factors such as physico-chemical properties of individual congeners and biological characteristics, such as sex, maturation state and, feeding habits, are all contributing factors to the accumulation of PCBs in fish. A correlation between lipid content and levels of PCB contaminants in liver and muscle of fish species, including eel (Anguilla anguilla), crucian carp (Carassius carassius) and catfish (Ictalurus nebulosus), was found by Roche et al. (2000). Even though it was infrequent, a negative correlation was observed in the fatty fish, eel, and a positive correlation in the non-fatty catfish. The negative correlation suggests that the youngest fish were the most contaminated. The positive

\section{Gonads: O. mossambicus}
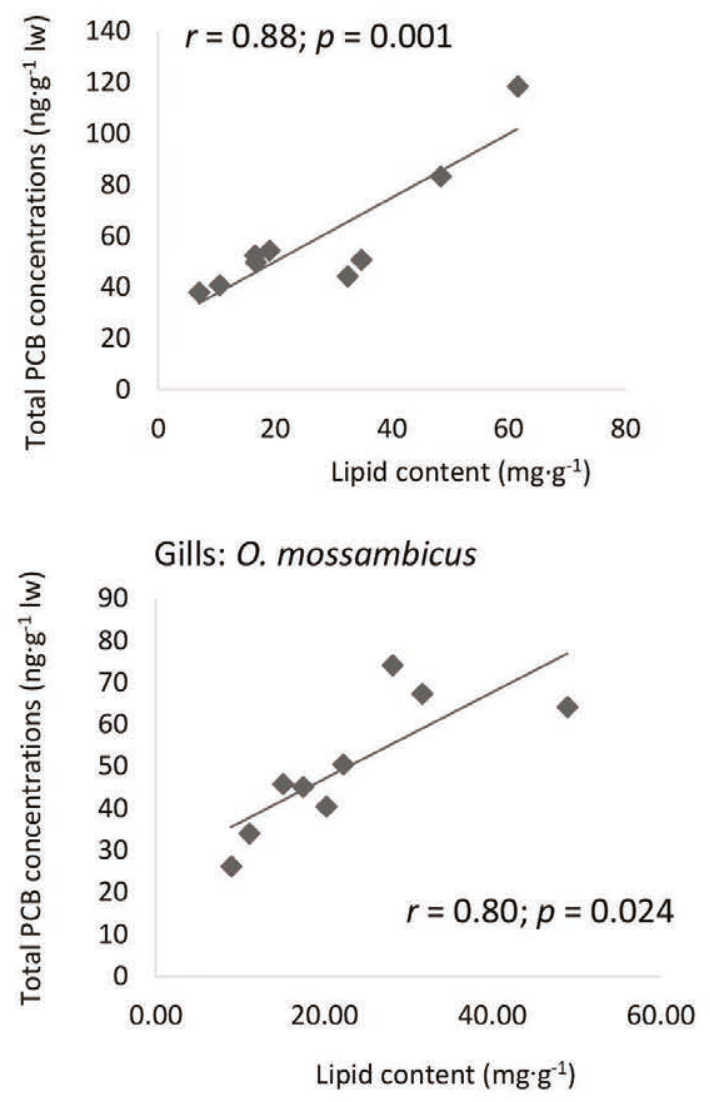

Muscle: $O$. mossambicus

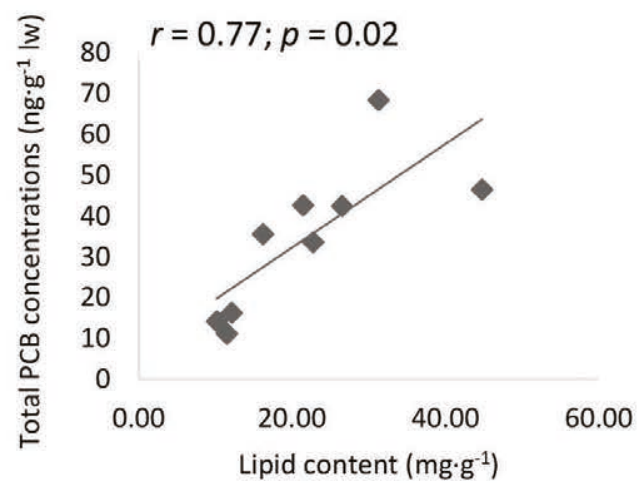

Liver: O. mossambicus

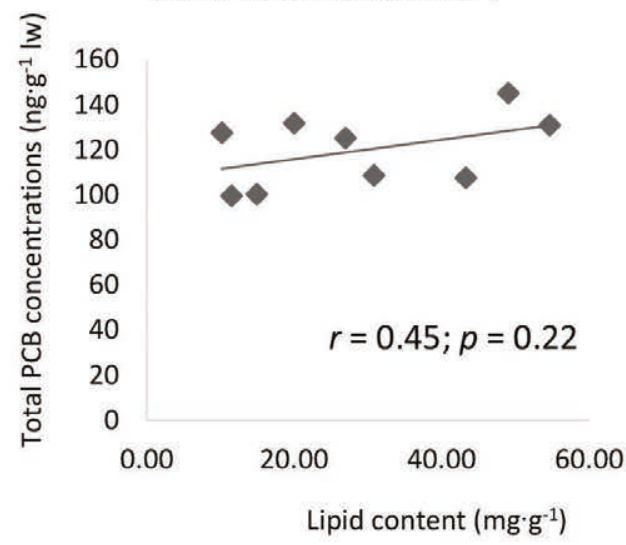

Figure 4a

$P C B$ concentrations versus lipid content in $\mathrm{O}$. mossambicus 
Liver: C. carpio

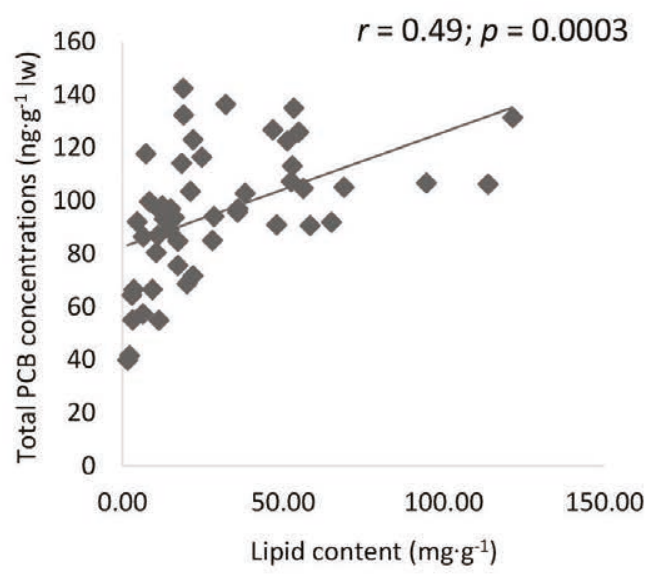

Gills: C. carpio

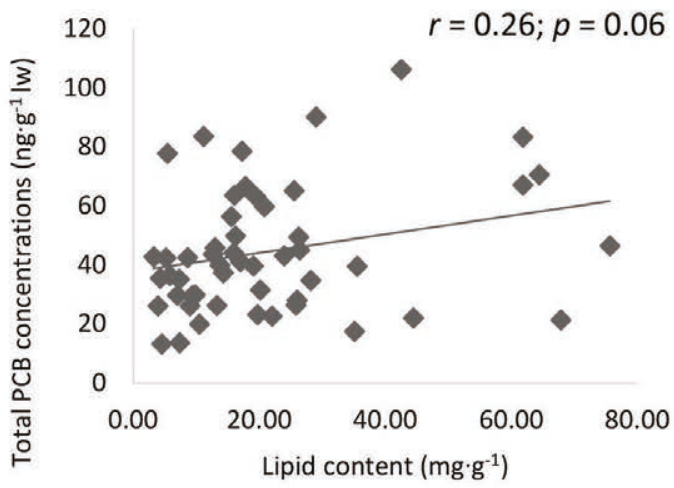

Gonads: C. carpio

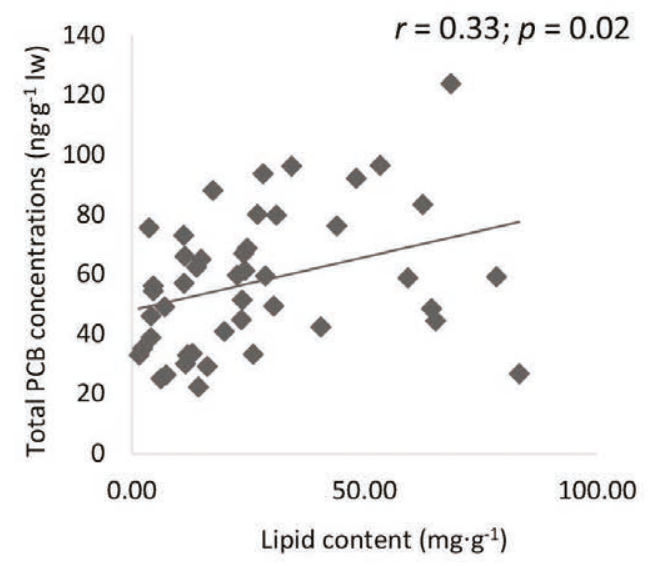

Muscle: $C$. carpio

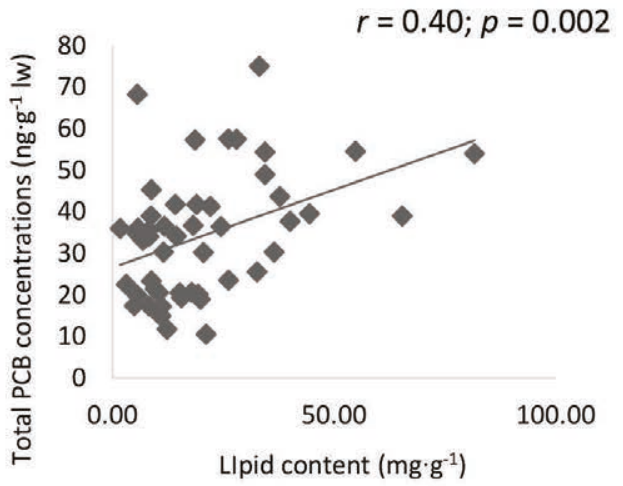

Figure $\mathbf{4 b}$

$P C B$ concentrations versus lipid content in $C$. carpio

relationship between lipid levels and organochlorine concentrations also tends to occur between species at the same trophic level, individuals of the same species, and within tissues in a single individual (Miller and Amrhein 1995). PCB contaminant levels have also been shown to be linked to the size of the fish samples (Boscher et al., 2010; Gewurtz et al., 2011). The condition factor (CF) values higher than 1 indicate healthy fishes. Compared to smaller fish of the same species, larger fish tend to consume larger, more contaminated prey and to eat at higher trophic levels. Thus, the foods of large fish tend to be more contaminated than the foods of small fish (Amrhein et al., 1999).

PCB levels detected in tissues of fish in this study showed a positive correlation between size of fish and body burdens of contaminants. The exception was found in liver and gonads of O. mossambicus. The size of fish can be reduced due to infections which can affect tissues. Fernandes et al. (2008) found that infected gonads showed a great reduction in size compared with non-infected ones. Mackay and Fraser (2000) proposed that the increase in concentration with size is due to the bioaccumulation properties of PCBs, their resistance to biotransformation and their slow depuration rates by organisms. Higher levels were expected in O. mossambicus in this study because of its predatory feeding habits compared to that of $C$. carpio (aquatic plants, benthic organisms, debris and detritus). However, no significant differences were observed between mean PCB concentrations of the same tissues of both fish species. In other studies on the tissues of fish, liver was found to be highly contaminated by the higher chlorinated congeners (i.e. PCBs 153 and 138) (Dabrowska et al., 2009; Wang et al., 2010; Brázová et al., 2012). With a high lipid content, the liver appears to be the main organ for metabolism and storage of PCBs (Fernandes et al., 2008; Bodiguel et al., 2009).

In general, PCB 153 is one of the main contributors to the total PCB content in freshwater fish species worldwide due to its long half-life (Nicola et al., 2014). PCBs 153 and 138, detected at high levels in this study, have been shown to initiate histological and neurological damage in the liver (Duffy and Zelikoff, 2006). Vezina et al. (2004) showed that after exposure to PCB 153 , rats, mice and monkeys exhibited liver damage. The estimation of hepatic sequestration showed that liver/muscle ratios for the sum of the six congeners were higher in O. mossambicus (4.92) compared to C. carpio (3.04). The bioaccumulation of PCBs in tissues is related to their logarithm octanol-water partition coefficient (log Kow). The lipophilicity and log Kow increase as the chlorine content increases thereby decreasing the biodegradability of PCB compounds (Semple et al., 2003; Zhou et al., 2005). The higher chlorinated congeners are less soluble in water and are therefore detected at higher levels in aquatic organisms. The bioaccumulation of PCBs in aquatic organisms is directly linked to their degree of chlorination and lipophilicity (Karjalainen et al., 2006).

Tissue-specific and congener distribution patterns are considered when evaluating the fate and effects of PCBs in the environment. However, no studies have been done on organs of 
fish in the region (South Africa) for comparison. Recent studies have been conducted, in other countries on tissue-specific PCB distribution in fish (Monosson et al., 2003; Bodiguel et al., 2009; Ondarza et al., 2010; Wang et al., 2010; Brázová et al., 2012; Lavandier et al., 2013). The levels of PCBs detected in organs of fish in the present study were compared with these studies (Table 4). Wang et al. (2010) measured total PCBs in muscle, gonads and liver of $C$. ursinus and found higher levels than that detected in the present study. Ondarza et al. (2010) reported PCB levels (for the same species, C. carpio) but results were expressed on wet weight. Brázová et al. (2012) conducted a study on predatory and non-predatory fish and reported PCB concentrations 3 orders of magnitude greater than the present study. Other researchers (Monosson et al., 2003, Bodiguel et al., 2009, Mierzykowski, 2010) have reported higher concentrations for some organs. The studies of Mierzykowski (2010) and Bodiguel et al. (2009) on sea fishes revealed higher ratios of liver/muscle (7.23 and 15.2) than those found in this study (4.92 and 3.04). Lavandier et al. (2013) analysed PCBs in 3 fish species from Sepetiba Bay in Brazil and the mean levels detected in scabbard fish muscle were similar to the levels detected in muscle of C. carpio in this study. All these studies showed that the values reported for the fish in the North End Lake were relatively low. In natural environments, fishes are exposed to a wide range of organic contaminants which behave differently in response to physico-chemical properties.
Major human exposure to PCBs occurs through food intake (WHO, 2000), and fish consumption is considered a significant potential route for this (Binelli and Provini, 2004; Ribeiro et al., 2008). Biomagnification of persistent contaminants is often observed as their elimination from tissues is slower than their uptake from food. Therefore, fish and animals at the top of the food chain are more contaminated than those feeding at lower trophic levels. Trimming the fat and skinning the fish prior to cooking may reduce the risk of exposure (USEPA, 1999a). Table 5 indicates maximum residue limits recommended by key international agencies.

Human consumption rates are based on the edible part of fish (muscle), but some ethnic groups may also eat various organs of fish. For example, Office of Environmental Health Hazard Assessment (OEHHA)'s California fish advisories has recommended that consumers not eat the liver and other organs of fish as they accumulate higher levels of organic contaminants relative to the muscle tissue (OEHHA, 2003). The USEPA has set a reference dose (RfD), which is defined as the daily exposure likely to be without significant risk of adverse effects during a lifetime. For total PCBs, the RfD is $2 \times 10^{-5}$ milligrams per kilogram of consumer body weight per day and cancer slope factor (CSF) of 2 (mg/[kg-d] $)^{-1}$ (USEPA, 2000). CSF is based on the cancer potency of the chemical used to estimate the probabilities of risk of developing cancer (USEPA, 1999b).

TABLE 4

Comparison of total PCB levels in fish organs of the present study and some locations elsewhere (ng. $\mathrm{g}^{-1} \mathbf{l} \mathbf{w}^{\mathrm{a}}$ and $\left.\mathbf{n g} \cdot \mathrm{g}^{-1} \mathbf{w w}\right)$.

\begin{tabular}{|c|c|c|c|c|c|c|}
\hline $\begin{array}{l}\text { Location } \\
\text { and year }\end{array}$ & Species & Liver & Gonads & Muscle & Gills & References \\
\hline \multirow{2}{*}{$\begin{array}{l}\text { North End } \\
\text { Lake, Port } \\
\text { Elizabeth, } \\
\text { South Africa }\end{array}$} & O. mossambicus $(n=9)$ & $119.73^{\mathrm{a}}$ & $59.21^{\mathrm{a}}$ & $34.63^{\mathrm{a}}$ & $49.78^{\mathrm{a}}$ & \multirow[b]{2}{*}{ Present study } \\
\hline & C. $\operatorname{carpio}(n=51)$ & $95.98^{\mathrm{a}}$ & $57.49^{\mathrm{a}}$ & $34.14^{\mathrm{a}}$ & $44.63^{\mathrm{a}}$ & \\
\hline $\begin{array}{l}\text { St. Paul Island, } \\
\text { USA } \\
2003-2004\end{array}$ & C. ursinus & $336.2^{\mathrm{a}}$ & $214.8^{\mathrm{a}}$ & $301.0^{\mathrm{a}}$ & - & Wang et al. (2010) \\
\hline $\begin{array}{l}\text { Negro River, } \\
\text { Argentina }\end{array}$ & C. carpio $(n=15)$ & 38.46 & 6.9 & 102.58 & 139.3 & Ondarza et al. (2010) \\
\hline \multirow{2}{*}{$\begin{array}{l}\text { Šíravský canal, } \\
\text { Slovakia, } 2009\end{array}$} & Predator fish $(n=24)$ & 120000 & 79400 & 99300 & - & \multirow{2}{*}{ Brázová et al. (2012) } \\
\hline & Non-predator fish $(n=8)$ & 70100 & 88200 & 64500 & - & \\
\hline $\begin{array}{l}\text { Rockall, } \\
\text { Scotland, } 2007\end{array}$ & Monkfish and scabbard fish & 892.5 & 1891.4 & 123.3 & - & Mierzykowski (2010) \\
\hline \multirow{2}{*}{$\begin{array}{l}\text { Gulf lions, N.W. } \\
\text { Mediterranean, } \\
2004-2005\end{array}$} & European hake males & 2539.5 & 58.7 & 167 & - & \multirow{2}{*}{ Bodiguel et al. (2009) } \\
\hline & Females & 1688.7 & 294.2 & 97.6 & - & \\
\hline \multirow{6}{*}{$\begin{array}{l}\text { Lower Hudson } \\
\text { River Estuary, } \\
1994\end{array}$} & F. heteroclitus (40 females) $)^{\mathrm{b}}$ : & & & & & \multirow{6}{*}{ Monosson et al. (2003) } \\
\hline & Flax site $^{\mathrm{b}}$ & 234 & 227 & 47 & - & \\
\hline & SSM site s. $^{\mathrm{b}}$ & 150 & 227 & 37 & - & \\
\hline & Newark site ${ }^{\mathrm{b}}$ & 1312 & 1596 & 209 & - & \\
\hline & Piermont site ${ }^{\mathrm{b}}$ & 1333 & 2547 & 255 & - & \\
\hline & Iona site ${ }^{\mathrm{b}}$ & 1265 & 3453 & 263 & - & \\
\hline \multirow{3}{*}{$\begin{array}{l}\text { Sepetiba Bay, } \\
\text { Brazil }\end{array}$} & Scabbard fish ${ }^{c}$ & $4.54-22.71$ & - & $3.97-11.04$ & - & \multirow{3}{*}{ Lavandier et al. (2013) } \\
\hline & Croaker $^{c}$ & $3.41-34.22$ & - & $2.29-25.88$ & - & \\
\hline & Mullet $^{\mathrm{c}}$ & $3.70-24.53$ & - & $2.37-27.60$ & - & \\
\hline
\end{tabular}

${ }^{a}$ Concentrations are expressed in lipid weight, NW: North-West

${ }^{b}$ Results are expressed as mean $P C B$ concentrations at these sites

${ }^{c}$ Results are given as a range of $P C B$ concentrations 


\begin{tabular}{|l|c|c|c|}
\hline \multicolumn{3}{|c|}{ Tolerance or maximum residue limit (MRL) (ng.g-1 fat basis) } \\
\hline Types of food & USFDA & Health Canada & EPA \\
\hline Milk (fat basis) & 1500 & 200 & - \\
\hline Dairy products (fat basis) & 1500 & 200 & - \\
\hline Poultry (fat basis) & 3000 & 500 & - \\
\hline Eggs & 300 & 100 & 2000 \\
\hline Meat, beef (fat basis) & - & 200 & - \\
\hline $\begin{array}{l}\text { Fish and shellfish (edible } \\
\text { portions) }\end{array}$ & 2000 & 2000 & 500 \\
\hline Infant and junior foods & 200 & - & 200 \\
\hline Drinking water & - & & \\
\hline
\end{tabular}

Sources: (ATSDR, 1990)

Based on the methodology developed by the USEPA (2000), the assessment of adult human health risks was evaluated by the determination of fish consumption limits expressed as number of meals per month of edible parts in both species (C. Carpio and O. mossambicus). For both species, based on the non-cancer health endpoint, four $8-\mathrm{oz}(0.227 \mathrm{~kg})$ meals per month are recommended and, based on the cancer health endpoint, one 8 -oz meal/month is recommended. Fish are nutritious, providing a good source of protein and other nutrients, and are recommended as part of a healthy balanced diet. However, considering contamination by PCBs and other lipophilic substances, it is advisable to consume fish in moderation and to make informed choices about which fish are safe to eat. For example, The American Heart Association recommends that healthy adults eat at least 2 servings of fish per week (Schwarzenegger et al., 2004).

This study showed that individual congeners were not distributed homogeneously within the investigated organs. Liver presented higher PCB concentrations than other tissues because liver is the main organ for PCB storage and has higher lipid content, therefore PCBs are more likely to accumulate in liver. The contamination levels of PCBs are the result of multiple factors affecting the fate of PCB congeners entering the aquatic environment. These factors include: the different degree of persistence for each congener, depending on the number of chlorine substitutions on the biphenyl rings, the physico-chemical properties of the PCB congeners (Kow, vapour pressure), and the prevailing percentage composition of the $\mathrm{PCB}$ commercial mixtures employed. The congeners detected in this study are dominant PCBs in technical PCB mixtures (Schulz-Bull et al., 1998).

\section{CONCLUSION}

This study is the first to report PCB contamination in the fishes of this lake, which receives stormwater inflow from industries and residential areas. The lipid contents of fish were found to be one of the main factors determining PCB levels in fish. Fish size, which is a proxy for fish age, is another important factor influencing the PCB levels in tissues. Based on the total PCB concentrations, O. mossambicus was more contaminated as it is a semi-predator while C. carpio is a bottom-feeder. C. carpio are omnivorous fish and they eat any food which can be digested. They dig and burrow into the soil in search of organic matter, such as larvae of insects, worms, molluscs and decayed matter containing bottom-dwelling organisms, pieces of plants and the young shoots of aquatic weeds.
Measurement of 6 indicator PCBs in tissues of Cyprinus carpio and Oreochromis mossambicus from the North End Lake have shown total PCB levels to decrease in the order: liver $>$ gonads $>$ gills $>$ muscles, in both species. The concentrations of total PCBs in the liver, gonads, gills and muscle were $95.69,57.49,44.63,34.14 \mathrm{ng} \cdot \mathrm{g}^{-1}$ lipid weight (lw) in C. carpio and $119.73,59.21,49.78,34.63{\mathrm{ng} \cdot \mathrm{g}^{-1}}(\mathrm{lw})$ in O. mossambicus, respectively.

The presence of PCBs in fish of the North End Lake could be harmful since they may be biomagnified through the food chain, i.e., with humans being the end consumer.

Fatty foods of animal origin constitute a potential source of PCB exposure. Based on the non-cancer and on the cancer health endpoint, four 8-oz $(227 \mathrm{~g})$ meals/month and one 8-oz meal/month were recommended for both species, respectively. Therefore, regulatory implementations for monitoring of wastewater emissions into this lake need to be implemented, as this is suspected to be the primary source of PCBs in the North End Lake.

\section{ACKNOWLEDGEMENTS}

The authors gratefully acknowledge the Nelson Mandela Metropolitan University (NMMU) and the University of Rwanda - College of Education for assistance and funding this study.

\section{REFERENCES}

AHMED FE (2003) Analysis of polychlorinated biphenyls in food products. Trends Anal. Chem. 22 (3) 170-185.

ATSDR (AGENCY FOR TOXIC SUBSTANCES AND DISEASE REGISTRY) (1990) Public Health Statement for PCBs. United States Department of Health and Human Services, Atlanta, GA.

ATSDR (AGENCY FOR TOXIC SUBSTANCES AND DISEASE REGISTRY) (2000) Toxicological profile for polychlorinated biphenyls (PCBs). Public Health Service, Agency for Toxic Substances and Disease Registry. United States Department of Health and Human Services, Atlanta, GA.

AMRHEIN JF, STOW CA and WIBLE C (1999) Whole-fish versus filet polychlorinated-biphenyl concentrations: An analysis using classification and regression tree models. Environ. Toxicol. Chem. 18 (8) 1817-1823.

ANTUNES P, AMADO J, VALE C and ODETE G (2007) Influence of the chemical structure on mobility of PCB congeners in female and male sardine (Sardina pilchardus) from Portuguese coast. Chemosphere 69 (3) 395-402. 
ANYASI RO and ATAGANA HI (2011) Biological remediation of polychlorinated biphenyls (PCB) in the environment by microorganisms and plants. Afr. J. Biotechnol. 10 (82) 18916-18938. DOI: 10.5897/AJB10.557.

AUNE M, ATUMA S, DARNERUD PO, WICKLUND-GLYNN A and CNATTINGIUS S (1999) Analysis of organochlorine compounds in human milk. Organohalogen Compd. 44 93-96.

BAEYENS W, LEERMAKERS M, ELSKENS M, VANLAREBEKE N, DEBONT R, VANDERPERREN H, FONTAINE A, DEGROODT J-M, GOEYENS L, HANOT V and WINDAL I (2007) PCBs and PCDD/FS in fish and fish products and their impact on the human body burden in Belgium. Arch. Environ. Contam. Toxicol. 52 563-571.

BAPTISTA J, PATO P, PEREIRA E, DUARTE AC and PARDAL MA (2013) PCBs in the fish assemblage of a southern European estuary. J. Sea Res. 76 22-30.

BEYER A AND BIZIUK M (2009) Environmental fate and global distribution of polychlorinated biphenyls. Rev. Environ. Contam. Toxicol. 201 137-158.

BINELLI A and PROVINI A (2004) Risk for human health of some POPs due to fish from Lake Iseo. Ecotoxic. Environ. Saf. 58 (1) 139-145.

BODIGUEL X, LOIZEAUA V, LE GUELLEC AM, ROUPSARD F, PHILIPPON X and MELLON-DUVAL C (2009) Influence of sex, maturity and reproduction on PCB and p, p' DDE concentrations and repartitions in the European hake (Merluccius merluc cius L.) from the Gulf of Lions (NW Mediterranean). Sci. Total Environ. 408 (2) 304-311.

BOSCHER A, GOBERT S, GUIGNARD C, ZIEBEL J, L'HOSTE L, GUTLEB AC, CAUCHIE HM, HOFFMANN L and SCHMIDT $\mathrm{G}$ (2010) Chemical contaminants in fish species from rivers in the north of Luxembourg: Potential impact on the Eurasian otter (Lutra lutra). Chemosphere 78 (7) 785-792.

BRÁZOVÁ T, HANZELOVÁ V and MIKLISOVÁ D (2012) Bioaccumulation of six PCB indicator congeners in a heavily polluted water reservoir in Eastern Slovakia: tissue-specific distribution in fish and their parasites. Parasitol. Res. 111 779-786.

BUSH B and KADLEC MJ (1995) Dynamics of PCBs in the aquatic environment. Great Lakes Res. Rev. 1 24-30.

CIMENCI O, VANDEVIJVERE S, GOSCINNY S, VAN DEN BERGH MA, HANOT V, VINKX C, BOLLE F and VAN LOCO J (2013) Dietary exposure of the Belgian adult population to non-dioxinlike PCBs. Food Chem. Toxicol. 59 670-679.

DABROWSKA H, BERNARD E, BARSKA I and RADTKE K (2009) Inter-tissue distribution and evaluation of potential toxicity of PCBs in Baltic cod (Gadus morhua L.). Ecotoxicol. Environ. Saf. 72 1975-1984.

DUFFY JE and ZELIKOFF JT (2006) The relationship between noncoplanar PCB-induced immunotoxicity and hepatic CYP1A induction in a fish model. J. Immunotoxic. 3 (1) 39-47.

EFSA (EUROPEAN FOOD SAFETY AUTHORITY) (2005) Opinion of the scientific panel on contaminants in the food chain on a request from the commission related to the presence of non-dioxin-like polychlorinated biphenyls (PCB) in feed and food. EFSA. J. 284 $1-137$.

FERNANDES D, ZANUY S, BEBIANNO MJ and PORTE C (2008) Chemical and biochemical tools to assess pollution exposure in cultured fish. Environ. Pollut. 152 (1) 138-146.

GDANIEC-PIETRYKA M, MECHLIŃSKA A, WOLSKA L, GAŁUSZKA A and NAMIEŚNIK J (2013) Remobilization of polychlorinated biphenyls from sediment and its consequences for their transport in river waters. Environ. Monit. Assess. 185 4449-4459.

GEWURTZ SB, BHAVSAR SP and FLETCHER R (2011) Influence of fish size and sex on mercury/PCB concentration: Importance for fish consumption advisories. Environ. Int. 37 424-434.

GEYER HJ, SCHEUNERT I, BRUEGGEMANN R, MATTHIES M, STEINBERG CEW, ZITKO V, KETTRUP A and GARRISON W (1994) The relevance of aquatic organisms lipid content to the toxicity of lipophilic chemicals: toxicity of lindane to different fish species. Ecotox. Environ. Saf. 28 53-70.

HENSHEL DS and SPARKS DW (2006) Site-specific PCB-linked interspecies differences in organ somatic indices. Ecotoxicology 15 9-18.
HEBERT CE and KEENLEYSIDE KA (1995) To normalize or not to normalize? Fat is the question. Environ. Toxicol. Chem. 14 801-807.

HITES RA, FORAN JA, CARPENTER DO, HAMILTON MC, KNUTH BA and SCHWAGER SJ (2004) Global assessment of organic contaminants in framed salmon. Science 303 226-229.

HU D, LEHMLER HJ, MARTINEZ A, WANG K and HORNBUCKLE KC (2010) Atmospheric PCB congeners across Chicago. Atmos. Environ. 44 (12) 1550-1557.

IWATA H, TANABE S, SAKAI N and TATSUKAWA R (1993) Distribution of persistent organochlorines in the oceanic air and surface seawater and the role of ocean on their global transport and fate. Environ. Sci. Technol. 271080.

KARJALAINEN A, PÄÄKKÖNEN J-PJ and KARJALAINEN J (2006) Tissue specific and whole fish accumulation of polychlorinated biphenyls by juvenile Baltic salmon (Salmo salar L.) after oral gavage exposure. Boreal Environ. Res. 11 421-430.

KOČAN A, PETRIK J, JURSA S, CHOVANCOVÁ J and DROBNÁ B (2001) Environmental contamination with polychlorinated biphenyls in the area of their former manufacture in Slovakia. Chemosphere 43 595-600.

LAVANDIER R, QUINETE N, HAUSER-DAVIS RA, DIAS PS, TANIGUCHI S, MONTONE R and MOREIRA I (2013) Polychlorinated biphenyls (PCBs) and polybrominated diphenyl ethers (PBDEs) in three fish species from an estuary in the southeastern coast of Brazil. Chemosphere 90 2435-2443.

MACKAY D and FRASER A (2000) Bioaccumulation of persistent organic chemicals: mechanisms and models. Environ. Pollut. $110375-391$.

MIERZYKOWSKI SE (2010) Environmental contaminants in tissues from an Atlantic sturgeon (Acipenser oxyrinchus) recovered in Wellfleet, Massachusetts. USFWS. Spec. Proj. Rep. FY09-MEFO-4EC. Maine Field Office. Orono, ME. 42 pp.

MILLER MA and AMRHEIN JF (1995) Maternal transfer of organochlorine compounds in Lake Superior siscowet (Salvelinus namaycush siscowet) to their eggs. Bull Environ. Contam. Toxicol. 55 (1) 96-103.

MONOSSON E, ASHLEY JTF, MCELROY AE, WOLTERING D and ELSKUS AA (2003) PCB congener distributions in muscle, liver and gonad of Fundulus heteroclitus from the Hudson River Estuary and Newark Bay. Chemosphere 52 777-787.

NICOLA GG, PARRA I, SÁEZ M, ALMODÓVAR A and JIMÉNEZ B (2014) Evaluation of PCBs and DDTs in endemic Iberian barbel Barbus bocagei (Steindachner, 1864) populations. Sci. Total Environ. 479 221-226.

NIE X, LAN C, WEI T and YANG Y (2005) Distribution of polychlorinated biphenyls in the water, sediment and fish from the Pearl River estuary, China. Mar. Pollut. Bull. 50 (5) 537-546.

OEHHA (OFFICE OF ENVIRONMENTAL HEALTH HAZARD ASSESSMENT) (2003) Methylmercury in sport fish: information for fish consumers. Pesticide and Environmental Toxicology Section, Office of Environmental Health Hazard Assessment, California Environmental Protection Agency. URL: http://www.oehha.ca.gov/fish/pdf/HGfacts.pdf (Accessed 23 September 2014)

ONDARZA PM, GONZALEZ M, SHIMABUKURO VM, AIZPÚN JE and MORENO VJ (2010) Organochlorine compounds in common carp (Cyprinus carpio) from Patagonia Argentina. J. Braz. Soc. Ecotoxicol. 5 41-547.

ONDARZA PM, GONZALEZ M, FILLMANN G and MIGLIORANZA KSB (2014) PBDEs, PCBs and organochlorine pesticides distribution in edible fish from Negro River basin, Argentinean Patagonia. Chemosphere 94 135-142.

OSPAR (2004) Polychlorinated biphenyls (PCBs). OSPAR Priority Substances, OSPAR Commission, London.

RIBEIRO CAO, VOLLAIRE Y, COULET E and ROCHE H (2008) Bioaccumulation of polychlorinated biphenyls in the eel (Anguilla anguilla) at the Camargue Nature Reserve, France. Environ. Pollut. 153 424-431.

ROCHE H, BUET A, JONOT O and RAMADE F (2000) Organochlorine residues in European eel (Anguilla anguilla), crucian carp (Carassius carassius) and catfish (Ictalurus nebulosus) from Vaccarès Lagoon (French National Nature Reserve 
of Camargue) - effects on some physiological parameters. Aquat. Toxicol. 48 (4) 443-459.

SCHULZ-BULL DE, PETRICK G, BRUHN R and DUINKER JC (1998) Chlorobiphenyls (PCB) and PAHs in water masses of the northern North Atlantic. Mar. Chem. 61 (1) 101-114.

SCHWARZENEGGER A, TAMMINEN T and DENTON JE (2004) Health advisory: guidelines for consumption of fish and shellfish from Tomales Bay (Marin County). Office of Environmental Health Hazard Assessment (OEHHA). California Environmental Protection Agency, Sacramento.

SEMPLE KT, MORRISS AWJ and PATON GI (2003) Bioavailability of hydrophobic organic contaminants in soils: fundamental concepts and techniques for analysis. Eur. J. Soil Sci.54 809-818.

TOASPERN ML (2003) Bioaccumulation of polychlorinated biphenyls in Delaware River Estuary. MSc thesis, University of Maryland.

UNEP (UNITED NATIONS ENVIRONMENT PROGRAMME) (2003) Proceedings of the UNEP workshop to develop a global POPs monitoring programme to support the effectiveness evaluation of the Stockholm Convention. UNEP Chemicals, Geneva, Switzerland.

URBANIAK M (2007) Polychlorinated biphenyls: sources, distribution and transformation in the environment-a literature review. Acta Toxicol. 15 (2) 83-93.

USEPA (UNITED STATES ENVIRONMENTAL PROTECTION AGENCY) (1996) Method 8082: PCBs by Gas Chromatography. USEPA, Washington, DC, USA.

USEPA (UNITED STATES ENVIRONMENTAL PROTECTION AGENCY) (2000a) Guidance for Assessing Chemical Contaminant Data for Use in Fish Advisories. Volume 1. Fish Sampling and Analysis ( $3^{\text {rd }} \mathrm{edn}$ ) Office of Science and Technology, Office of Water, Washington, DC.

USEPA (UNITED STATES ENVIRONMENTAL PROTECTION AGENCY) (2000) Guidance for Assessing Chemical Contaminant
Data for Use in Fish Advisories. Volume 2. Risk Assessment and Fish Consumption Limits ( $3^{\text {rd }} \mathrm{edn}$ ). United States Environmental Protection Agency, Washington, DC. URL: http://www.epa.gov/ waterscience/fish/advice/volume2/ (Accessed 10 April 2014).

USEPA (UNITED STATES ENVIRONMENTAL PROTECTION AGENCY) (1999a) Polychlorinated Dibenzo-p-dioxins and Related Compounds Update: Impact on Fish Advisories. Office of Water 4305. EPA-823-F-99-015. USEPA, Washington, DC.

USEPA (UNITED STATES ENVIRONMENTAL PROTECTION AGENCY) (1999b) Integrated Risk Information System (IRIS) on PCBs. National Center for Environmental Assessment, Office of Research and Development. USEPA, Washington, DC.

VEZINA CM, WALKER NJ and OLSON JR (2004) Subchronic exposure to TCDD, PeCDF, PCB126, and PCB153: Effect on hepatic gene expression. Environ. Health Persp. 112 1636-1644.

WANG D, SHELVER WL, ATKINSON S, MELLISH JA and LI QX (2010) Tissue distribution of polychlorinated biphenyls and organochlorine pesticides and potential toxicity to Alaskan Northern fur seals assessed using PCB congener specific mode of action schemes. Arch. Environ. Contam. Toxicol. 58 478-488.

WEICHERS HNS, FREEMAN MJ and HOWARD MR (1996) The management of urban impoundments in South Africa, Volume 1: Status quo report. WRC Report No. TT 77/96. Water Research Commission, Pretoria. 89 pp.

WORLD HEALTH ORGANIZATION REGIONAL OFFICE FOR EUROPE (2000) Air Quality Guidelines (2 ${ }^{\text {nd }}$ edn). Cap 5.10 PCB. WHO Regional Publications, European Series, No. 91. WHO, Copenhagen, Denmark.

ZHOU W, ZHAI Z, WANG Z and WANG L (2005) Estimation of n-octanol/water partition coefficients (Kow) of all PCB congeners by density functional theory. J. Mol. Struct. 755 137-145. 